\title{
Developing Multilayer Thin Film Strain Sensors With High Thermal Stability
}

John D. Wrbanek and Gustave C. Fralick

Glenn Research Center, Cleveland, Ohio

José M. Gonzalez III

Gilcrest Electric and Supply Company, Cleveland, Ohio 


\section{NASA STI Program . . . in Profile}

Since its founding, NASA has been dedicated to the advancement of aeronautics and space science. The NASA Scientific and Technical Information (STI) program plays a key part in helping NASA maintain this important role.

The NASA STI Program operates under the auspices of the Agency Chief Information Officer. It collects, organizes, provides for archiving, and disseminates NASA's STI. The NASA STI program provides access to the NASA Aeronautics and Space Database and its public interface, the NASA Technical Reports Server, thus providing one of the largest collections of aeronautical and space science STI in the world. Results are published in both non-NASA channels and by NASA in the NASA STI Report Series, which includes the following report types:

- TECHNICAL PUBLICATION. Reports of completed research or a major significant phase of research that present the results of NASA programs and include extensive data or theoretical analysis. Includes compilations of significant scientific and technical data and information deemed to be of continuing reference value. NASA counterpart of peer-reviewed formal professional papers but has less stringent limitations on manuscript length and extent of graphic presentations.

- TECHNICAL MEMORANDUM. Scientific and technical findings that are preliminary or of specialized interest, e.g., quick release reports, working papers, and bibliographies that contain minimal annotation. Does not contain extensive analysis.

- CONTRACTOR REPORT. Scientific and technical findings by NASA-sponsored contractors and grantees.
- CONFERENCE PUBLICATION. Collected papers from scientific and technical conferences, symposia, seminars, or other meetings sponsored or cosponsored by NASA.

- SPECIAL PUBLICATION. Scientific, technical, or historical information from NASA programs, projects, and missions, often concerned with subjects having substantial public interest.

- TECHNICAL TRANSLATION. Englishlanguage translations of foreign scientific and technical material pertinent to NASA's mission.

Specialized services also include creating custom thesauri, building customized databases, organizing and publishing research results.

For more information about the NASA STI program, see the following:

- Access the NASA STI program home page at http://www.sti.nasa.gov

- E-mail your question via the Internet to help@sti.nasa.gov

- Fax your question to the NASA STI Help Desk at 301-621-0134

- Telephone the NASA STI Help Desk at 301-621-0390

- Write to:

NASA STI Help Desk

NASA Center for AeroSpace Information 7121 Standard Drive Hanover, MD 21076-1320 


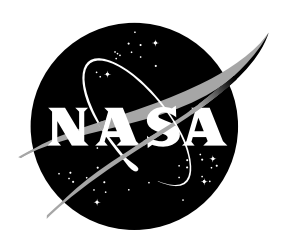

\section{Developing Multilayer Thin Film Strain Sensors With High Thermal Stability}

John D. Wrbanek and Gustave C. Fralick

Glenn Research Center, Cleveland, Ohio

José M. Gonzalez III

Gilcrest Electric and Supply Company, Cleveland, Ohio

42nd Joint Propulsion Conference and Exhibit cosponsored by the AIAA, ASME, SAE, and ASEE

Sacramento, California, July 9-12, 2006

National Aeronautics and

Space Administration

Glenn Research Center

Cleveland, Ohio 44135 


\section{Acknowledgments}

We extend our thanks to Kimala Laster of Sierra Lobo, Inc. for her assistance in data acquisition and Chuck Blaha of Jacobs Sverdrup for his assistance in the device fabrication. We gratefully acknowledge the support of the staff of the NASA Glenn test Facilities Operation, Maintenance, and Engineering (TFOME) organization in maintaining the fabrication and test equipment capabilities of the Glenn Microsystems Fabrication Clean Room Facility. We also thank Dr. Jennifer C. Xu of the Sensors and Electronics Branch for reviewing this work. The work presented here was sponsored by the Prop21 and

Hypersonics Projects of the Fundamental Aeronautics Program as part of NASA's Aeronautics Research Missions Directorate.

This report is a formal draft or working paper, intended to solicit comments and ideas from a technical peer group.

This report contains preliminary findings, subject to revision as analysis proceeds.

This work was sponsored by the Fundamental Aeronautics Program at the NASA Glenn Research Center.

Level of Review: This material has been technically reviewed by technical management.

Available from

NASA Center for Aerospace Information 7121 Standard Drive

Hanover, MD 21076-1320
National Technical Information Service 5285 Port Royal Road Springfield, VA 22161 


\title{
Developing Multilayer Thin Film Strain Sensors With High Thermal Stability
}

\author{
John D. Wrbanek and Gustave C. Fralick \\ National Aeronautics and Space Administration \\ Glenn Research Center \\ Cleveland, Ohio 44135 \\ José M. Gonzalez III \\ Gilcrest Electric and Supply Company \\ Brook Park, Ohio 44142
}

\begin{abstract}
A multilayer thin film strain sensor for large temperature range use is under development using a reactivelysputtered process. The sensor is capable of being fabricated in fine line widths utilizing the sacrificial-layer lift-off process that is used for microfabricated noble-metal sensors. Tantalum nitride films were optimized using reactive sputtering with an unbalanced magnetron source. A first approximation model of multilayer resistance and temperature coefficient of resistance was used to set the film thicknesses in the multilayer film sensor. Two multifunctional sensors were fabricated using multilayered films of tantalum nitride and palladium chromium, and tested for low temperature resistivity, TCR and strain response. The low temperature coefficient of resistance of the films will result in improved stability in thin film sensors for low to high temperature use.
\end{abstract}

\section{Nomenclature}

$\begin{array}{ll}\mathrm{CTE} & \text { coefficient of thermal expansion }\left(\mathrm{ppm} /{ }^{\circ} \mathrm{C}\right) \\ d & \text { film thickness }(\AA) \\ \varepsilon & \text { strain; change per unit length }(\mu \varepsilon) \\ \varepsilon_{a} & \text { apparent strain due to temperature rather than applied strain }(\mu \varepsilon) \\ \delta \varepsilon_{a} / \delta T & \text { apparent strain sensitivity to temperature changes }\left(\mu \varepsilon /{ }^{\circ} \mathrm{C}\right) \\ \gamma & \text { gauge factor of strain gauge } \\ \delta l / l & \text { length change per unit length }(\varepsilon) \\ \mu \varepsilon & \text { unit of microstrain; typically defined as } 10^{-6} \text { inch change per inch length }(\mu \mathrm{in} / \mathrm{in}) \\ \mathrm{PdCr} & \text { palladium chromium alloy } \\ \rho & \text { electrical resistivity }(\mu \Omega-\mathrm{cm}) \\ \sigma & \text { electrical conductivity }(\Omega \text {-cm }) \\ \mathrm{TaN} & \text { tantalum nitride }(\text { no specific phase }) \\ \mathrm{TCR} & \text { temperature coefficient of resistance }\left(\mathrm{ppm} /{ }^{\circ} \mathrm{C}\right)\end{array}$

\section{Introduction}

\section{A. Challenge of Sensors for Propulsion Systems}

To advance knowledge in fundamental aeronautics and develop technologies for safer, lighter, quieter, and more fuel efficient aircraft, instrumentation technologies are being developed by the National Aeronautics and Space Administration (NASA) in support of its mission to pioneer the future in space exploration, scientific discovery, and aeronautics research. These technologies also enable the capabilities for long duration, more distant human and robotic missions for the Vision for Space Exploration.

The Sensors and Electronics Branch of NASA Glenn Research Center (GRC) has an in-house effort to develop thin film sensors for surface measurement in propulsion system research. The sensors include those for strain, temperature, heat flux and surface flow which will enable critical vehicle health monitoring and characterization of components of future space and air vehicles.

The use of sensors made of thin films has several advantages over wire or foil sensors. Thin film sensors do not require special machining of the components on which they are mounted, and, with thicknesses less than $10 \mu \mathrm{m}$, 
they are considerably thinner than wire or foils. Thin film sensors are thus much less disturbing to the operating environment, and have a minimal impact on the physical characteristics of the supporting components.

The need to consider ceramic sensing elements is brought about by the temperature limits of metal thin film sensors in propulsion system applications. Longer-term stability of thin film sensors made of noble metals has been demonstrated at $1100{ }^{\circ} \mathrm{C}$ for $25 \mathrm{hr}$ (ref. 1) The capability for thin film sensors to operate in $1500{ }^{\circ} \mathrm{C}$ environments for $25 \mathrm{hr}$ or more is considered critical for ceramic turbine engine development (refs. 2 and 3). For future space transportation vehicles, temperatures of propulsion system components of at least 1650 to $3000{ }^{\circ} \mathrm{C}$ are expected (ref. 4).

\section{B. Limits of Metal Film Sensors}

A limitation of thin films used as sensors to measure strain is that their resistance changes as the temperature changes. This apparent strain $\left(\varepsilon_{a}\right)$ can be falsely interpreted as actual strain on the component being monitored. For static strain applications for use on gas turbine engines, the current required accuracy is $\pm 200 \mu \mathrm{in} / \mathrm{in}(\mu \varepsilon)$, approximately \pm 10 percent of full scale, with the goal of \pm 1 percent accuracy (ref. 5). The thin film palladiumchromium (PdCr) alloy strain gauge, developed at NASA GRC for high temperature strain measurement application, is stable to $1100{ }^{\circ} \mathrm{C}$, but has a temperature coefficient of resistance (TCR) of $135 \mathrm{ppm} /{ }^{\circ} \mathrm{C}$ and an apparent strain sensitivity $\left(\delta \varepsilon_{a} / \delta T\right)$ of $85 \mu \varepsilon /{ }^{\circ} \mathrm{C}$, requiring temperature compensation for high temperature static strain measurements (refs. 1 and 5). Currently, this compensation is in the form of setting a "ballast" potentiometer in a bridge to perform first order elimination of the apparent strain at a particular temperature, but deviations from this matched temperature results in measured apparent strain (ref. 6).

A thin film multifunctional sensor developed at NASA GRC that can measure directional strain, flow, heat flux, and temperature utilizes this $\mathrm{PdCr}$ alloy (ref. 7), but does not incorporate a compensation bridge in its design and is limited to dynamic strain measurements at high temperature. A thin film strain sensor with thermal stability over a wide range of temperatures would allow high temperature static measurements with the multifunctional sensor as well as a more passive method of eliminating apparent strain without the need for a compensation bridge. NASA GRC has thus begun an in-house effort to develop thin film strain sensors with high thermal stability. Ultimately, the goal is to be able to achieve the desired $\pm 20 \mu \varepsilon$ accuracy of measured applied static strain being no less than 0.1 percent of a total strain measurement (= applied + apparent + drift strain), or $\pm 20,000 \mu \varepsilon$. The total apparent strain of $20,000 \mu \varepsilon$ limits the desired apparent strain sensitivity to temperature to be less than $\pm 20 \mu \varepsilon /{ }^{\circ} \mathrm{C}$ over the current temperature range. As this goal is approached, the drift strain (creep) will also be considered as part of the total strain measurement.

\section{Ceramic-Based Film Sensor Development}

\section{A. Background}

Since 1991, there have been many investigations into the application of ceramic thin films for use as high temperature thin film strain gauges. A summary of notable high temperature thin film strain gauges is given in table 1. Thin film resistors for regulating electronics based on doped nickel-chromium alloy films with a TCR of $\pm 5 \mathrm{ppm} /{ }^{\circ} \mathrm{C}$ and greater are common in the electronics industry, but they are generally restricted to a temperature range between -55 to $125^{\circ} \mathrm{C}$ (ref. 8), and thus not suitable for our applications.

TABLE 1.-A REVIEW OF HIGH TEMPERATURE THIN FILM STRAIN GAUGE APPLICATIONS

\begin{tabular}{|c|c|c|c|c|c|c|}
\hline $\begin{array}{c}\text { Gauge } \\
\text { material }\end{array}$ & $\begin{array}{c}\mathrm{TCR} \\
\left(\mathrm{ppm} /{ }^{\circ} \mathrm{C}\right)\end{array}$ & $\begin{array}{c}\text { Gauge factor } \\
(\gamma)(\delta R / R \varepsilon)\end{array}$ & $\begin{array}{c}\text { Apparent } \\
\text { strain } \\
\text { sensitivity } \\
\left(\mu \varepsilon /{ }^{\circ} \mathrm{C}\right)\end{array}$ & $\begin{array}{c}\text { Maximum use } \\
\text { temperature } \\
\text { (if reported) }\end{array}$ & Fabrication notes & Ref. \\
\hline $\mathrm{Ni}-20 \% \mathrm{Cr}$ & 290 & 2.5 & 116 & $700{ }^{\circ} \mathrm{C}$ & COTS standard & 14,15 \\
\hline $\mathrm{Pd}-13 \% \mathrm{Cr}$ & 135 & 2 to 1.4 & 85 & $1100{ }^{\circ} \mathrm{C}$ & NASA standard & 1 \\
\hline $\mathrm{AlN}$ & -1281 to 109 & 3.72 to 15 & -344 to 29 & $>1100{ }^{\circ} \mathrm{C}$ & Al reacted with $\mathrm{N}$ & 16 \\
\hline $\mathrm{ITO}$ & -469 to 230 & -6.5 to 11.4 & -35 to 72 & $>1100{ }^{\circ} \mathrm{C}$ & Oxygen doping & 17 \\
\hline $\mathrm{Al}: \mathrm{ITO}$ & -1200 & 8 & -150 & $1280{ }^{\circ} \mathrm{C}$ & Aluminum doping & 18 \\
\hline $\mathrm{TiB} 2$ & -50 & 1.4 & -36 & $<3225{ }^{\circ} \mathrm{C}$ & Nitrogen doping & 19 \\
\hline $\mathrm{Cu}: \mathrm{TaN}$ & -800 to 200 & 2.3 to 5.1 & -348 to 87 & (not reported) & Ta reacted w/N; Cu doping & 20 \\
\hline $\mathrm{TaN}$ & -80 & 3.5 & -23 & (not reported) & Ta reacted with $\mathrm{N}$ & 21 \\
\hline $\mathrm{TaON}$ & -290 & 3.5 & -83 & (not reported) & $\begin{array}{c}\text { Ta reacted with } \mathrm{N} ; \\
1 \text { percent Ox }\end{array}$ & 22 \\
\hline
\end{tabular}


The gauge factor $(\gamma)$ of the strain gauge relates the sensitivity of the gauge to strain $(\varepsilon=\delta l / l)$, as shown in equation (1).

$$
\frac{\delta R}{R}=\gamma \frac{\delta l}{l}=\gamma \varepsilon
$$

The apparent strain sensitivity to temperature $\left(\delta \varepsilon_{a} / \delta T\right)$ is the TCR divided by the gauge factor plus the difference in the substrate and the gauge material's coefficient of thermal expansion (CTE), as shown in equation (2). The difference in the CTE's is expected to be less than $5 \mathrm{ppm} /{ }^{\circ} \mathrm{C}$ based on the materials that we are exploring, and this will be left as an uncertainty in our apparent strain calculation.

$$
\frac{\delta \varepsilon_{a}}{\delta T}=\frac{\mathrm{TCR}}{\gamma}+\Delta \mathrm{CTE}
$$

Based on the reported gauges in table 1, the maximum use temperature of tantalum nitride (TaN) may be up to $2000{ }^{\circ} \mathrm{C}$, the most attractive for high temperature applications. As a thin film, TaN is known as a stable high temperature resistor with TCR between 200 and $-200 \mathrm{ppm} /{ }^{\circ} \mathrm{C}$, depending on the fabrication process, nitride phase produced (e.g., $\mathrm{Ta}_{2} \mathrm{~N}, \mathrm{TaN}_{1} \mathrm{Ta}_{5} \mathrm{~N}_{6}$, etc.), incorporation of oxide on the TaN grains and the degree of amorphous structure (refs. 9 to 12). The report of studies (refs. 13) of resistors using $\mathrm{NiCr}$ and $\mathrm{TaNiCr}$ interlayers with $\mathrm{Ta}_{2} \mathrm{~N}$ to achieve TCR between 5 and $-5 \mathrm{ppm} /{ }^{\circ} \mathrm{C}$ began our investigation to develop a tantalum nitride film for use with the $\mathrm{PdCr}$ strain gauge to achieve the passive elimination of apparent strain sensitivity.

\section{B. Tantalum Nitride Film Fabrication}

The first step to developing an interlayered or multilayered TaN/PdCr film was to develop a process of reactively sputtering the tantalum nitride consistently. The first depositions were on alumina substrates with the film resistivity measured using a four-point probe (ref. 23) with spacing of $2.54 \mathrm{~mm}$. The resistivity of $\operatorname{Ta}_{2} \mathrm{~N}$ films can vary between 200 and $264 \mu \Omega-\mathrm{cm}$, again due to the incorporation of oxide and degree of amorphous structure (refs. 9 to 12). The results of these first runs are given in table 2 . The resistivities given in the table are considered accurate to \pm 1.8 percent.

TABLE 2.-TANTALUM NITRIDE DEPOSITIONS

\begin{tabular}{|c|c|c|c|c|c|c|c|c|}
\hline Sample & $\begin{array}{c}\text { RF power } \\
(\mathrm{W})\end{array}$ & $\begin{array}{c}\text { Process } \\
\text { pressure } \\
(\mathrm{mT})\end{array}$ & $\begin{array}{c}\text { Argon } \\
\text { flow } \\
(\mathrm{sccm})\end{array}$ & $\begin{array}{c}\text { Nitrogen } \\
\text { flow } \\
(\mathrm{sccm})\end{array}$ & $\begin{array}{c}\text { Run time } \\
(\mathrm{sec})\end{array}$ & $\begin{array}{c}\text { Film } \\
\text { thickness } \\
(\mu \mathrm{m})\end{array}$ & $\begin{array}{c}\text { Resistivity } \\
\rho(\mu \Omega-\mathrm{cm})\end{array}$ & $\begin{array}{c}\mathrm{TCR} \\
\left(\mathrm{ppm} /{ }^{\circ} \mathrm{C}\right)\end{array}$ \\
\hline JG40901 & 250 & 8 & 20 & 0 & 3600 & 1.8 & 74 & ---- \\
\hline JG40903 & 250 & 8 & 20 & 2 & 7200 & 2.2 & 383 & ---- \\
\hline JG40908 & 250 & 8 & 38 & 2 & 7200 & 5.0 & 265 & ---- \\
\hline JG40909 & 250 & 8 & 38 & 2 & 7200 & 4.8 & 269 & --- \\
\hline JG40922 & 250 & 8 & 38 & 2 & 7200 & 3.9 & 259 & -93 \\
\hline JG41123 & 250 & 4 & 38 & 2 & 7200 & 3.7 & 232 & -400 \\
\hline JG41124 & 250 & 3 & 38 & 2 & 7200 & 3.7 & 269 & -100 \\
\hline JG50114 & 250 & 3 & 38 & 2 & 3600 & 3.7 & 440 & -110 \\
\hline JG50115 & 125 & 2 & 38 & 2 & 3600 & 1.0 & 155 & -200 \\
\hline
\end{tabular}

The confidence gained with the results of the last two runs resulted in the fabrication of a multifunctional sensor (run JG40922) with a length to width ratio (1/w) of 290 of tantalum nitride using the run parameters of runs JG40908 and JG40909. The sensor was patterned using the sacrificial-layer lift-off process that is used for microfabricated noble-metal sensors of fine line widths (ref. 24). The completed sensor is shown in figure 1. The TCR was measured to be $-93 \mathrm{ppm} /{ }^{\circ} \mathrm{C}$, and the resistivity $259 \mu \Omega-\mathrm{cm}$. The strain sensitivity was measured using the algorithm developed for the sensor (ref. 7), and the gauge factor was found to be $3.9 \pm 0.1$, and the angle resolution was determined to be less than $\pm 0.2^{\circ}$. This translates to an apparent strain sensitivity of $-24 \mu \varepsilon /{ }^{\circ} \mathrm{C}$, similar to what was reported by Ayerdi, et al. (ref. 21) and close to our goal of $< \pm 20 \mu \varepsilon /{ }^{\circ} \mathrm{C}$. A graph showing the output of the gauge factor $\times$ applied strain versus the applied strain is shown in figure 2. 


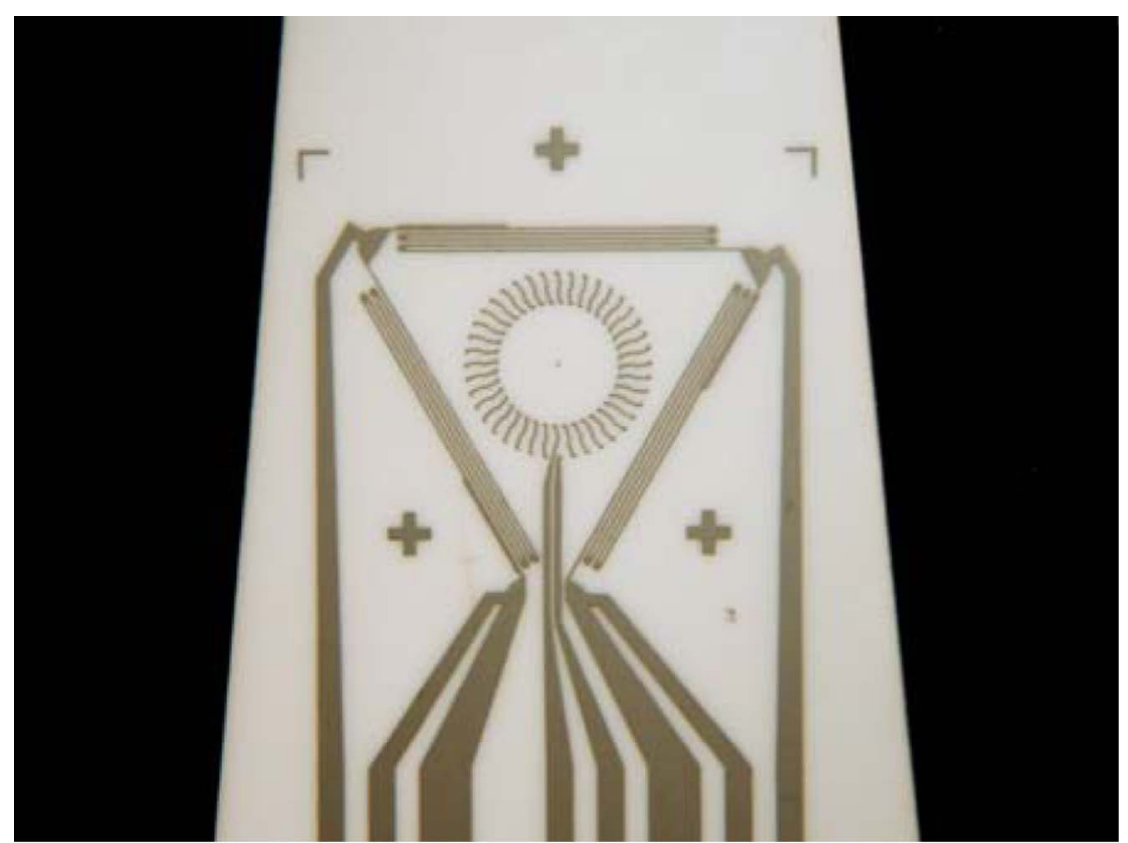

Figure 1.-TaN multifunctional sensor (run JG40922).

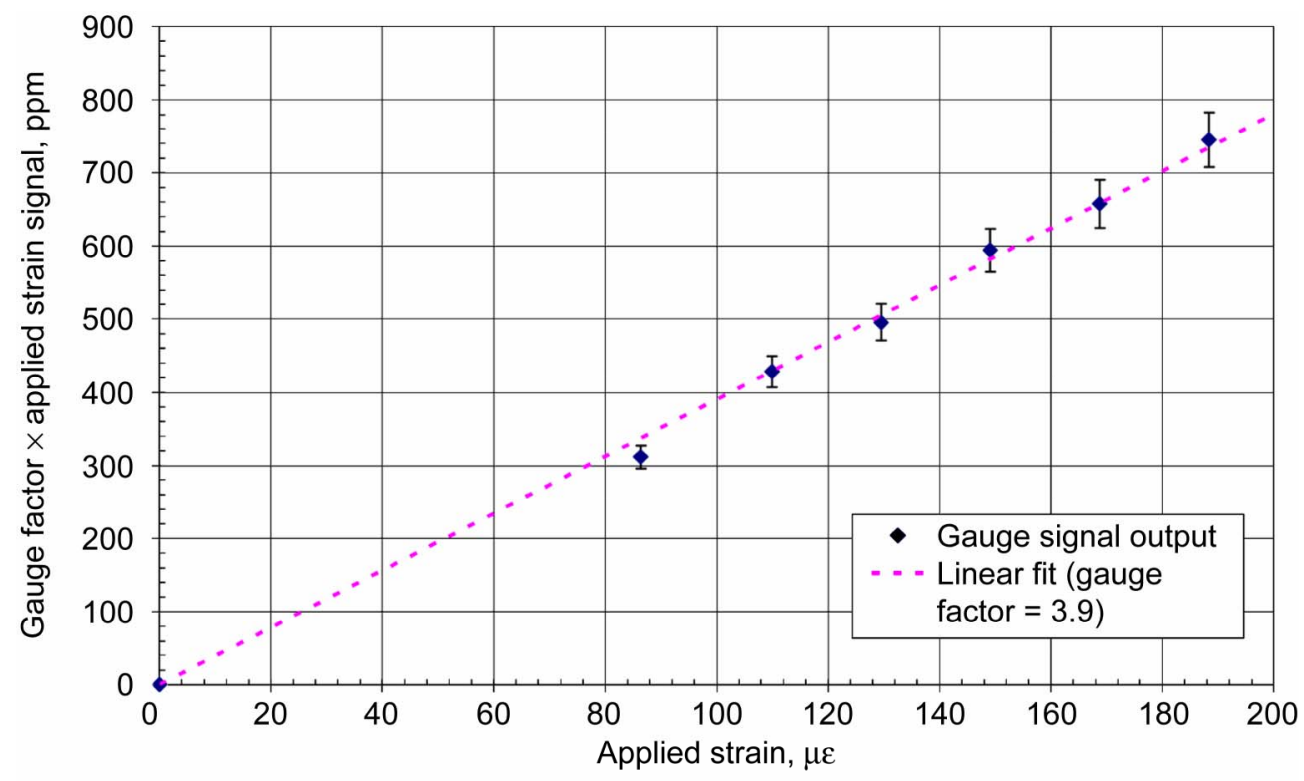

Figure 2.-Strain output of the TaN multifunctional sensor (run JG40922) at room temperature. Error bars reflect $\pm 5 \%$ uncertainty in the measurement.

Target arcing and degradation, however, was becoming an issue, with the thickness of the sensor of run JG40922 about 20 percent less than the initial runs JG40908 and JG40909. For the next set of runs, the system pressure and power were lowered to prevent the arcing and degradation of the tantalum target. The films were pattered using a shadow mask with $\mathrm{l} / \mathrm{w}=21.88$, allowing the resistivity to be measured as well as the TCR using a four wire method with a data acquisition system. The resulting film of run JG50115 had a TCR of $-200 \mathrm{ppm} /{ }^{\circ} \mathrm{C}$ and a resistivity of $155 \mu \Omega$-cm. 


\section{Multilayered Film Fabrication}

\section{A. Multilayer Film Approach}

Once the TaN film deposition parameters were finalized, the multilayered $\mathrm{TaN} / \mathrm{PdCr}$ films were attempted. A cross-section schematic of the multilayered film is shown in figure 3. As an estimate for the relative thicknesses, the assumption is made that because the film thicknesses (d) are greater than the grain size, and thus electron mean free path, the films can be treated as three independent layers in parallel (to first approximation) (ref. 25).

The conductivity $(\sigma)$ is the inverse of the resistivity $(\rho)$, and because the first and last layers are the same material $(\mathrm{TaN})$ and the second is $\mathrm{PdCr}$, the conductivities add as in equation (3).

$$
\sigma_{\text {Total }}=\sigma_{\text {TaN }} \frac{d_{\text {TaN }}}{d_{\text {Total }}}+\sigma_{\text {PdCr }} \frac{d_{\text {PdCr }}}{d_{\text {Total }}}
$$

Similarly, the TCR $(\alpha)$ for multiple layers is derived as in equation (4).

$$
a_{\mathrm{Total}}=\frac{d_{\mathrm{TaN}} \sigma_{\mathrm{TaN}} a_{\mathrm{TaN}}+d_{\mathrm{PdCr}}}{d_{\mathrm{TaN}} \sigma_{\mathrm{TaN}}+d_{\mathrm{PdCr}} \sigma_{\mathrm{PdCr}}}=\frac{d_{\mathrm{TaN}} \sigma_{\mathrm{TaN}} \alpha_{\mathrm{TaN}}+d_{\mathrm{PdCr}} \sigma_{\mathrm{PdCr}} \alpha_{\mathrm{PdCr}}}{d_{\mathrm{Total}} \sigma_{\mathrm{Total}}}
$$

To cancel out the TCR, the numerator is set to zero, as shown in equation (5).

$$
d_{T a N} \sigma_{T a N} \alpha_{T a N}=-d_{P d C r} \sigma_{P d C r} \alpha_{P d C r}
$$

The ratio of PdCr film thickness to TaN film thickness then can be derived in equation (6).

$$
\frac{d_{\mathrm{PdCr}}}{d_{\mathrm{TaN}}}=-\frac{\sigma_{\mathrm{TaN}}}{\sigma_{\mathrm{PdCr}}} \frac{\alpha_{\mathrm{TaN}}}{\alpha_{\mathrm{PdCr}}}=-\frac{\rho_{\mathrm{PdCr}}}{\rho_{\mathrm{TaN}}} \frac{\alpha_{\mathrm{TaN}}}{\alpha_{\mathrm{PdCr}}}
$$

So, to a first approximation, the TCR of the multilayer can be minimized with the knowledge of the resistivity and TCR of the component films. Using the values of TaN from JG50115, and the resistivity and TCR of PdCr as $110 \mu \Omega-\mathrm{cm}$ and $170 \mathrm{ppm} /{ }^{\circ} \mathrm{C}$ respectively, the ratio of PdCr to TaN thickness to cancel the multilayer film TCR is found to be 0.835 .

\begin{tabular}{|c|c|}
\hline \multirow{3}{*}{ Electrode } & Tantalum oxide \\
\cline { 2 - 3 } & Tantalum nitride $\left(\mathrm{Ta}_{2} \mathrm{~N}\right)$ \\
\cline { 2 - 3 } & Palladium-chromium alloy $(\mathrm{Pd} 13 \mathrm{Cr})$ \\
\cline { 2 - 3 } & Tantalum nitride $\left(\mathrm{Ta}_{2} \mathrm{~N}\right)$ \\
\hline
\end{tabular}

Alumina substrate coating

Figure 3.-A cross-section schematic of the multilayer thin film sensor. 


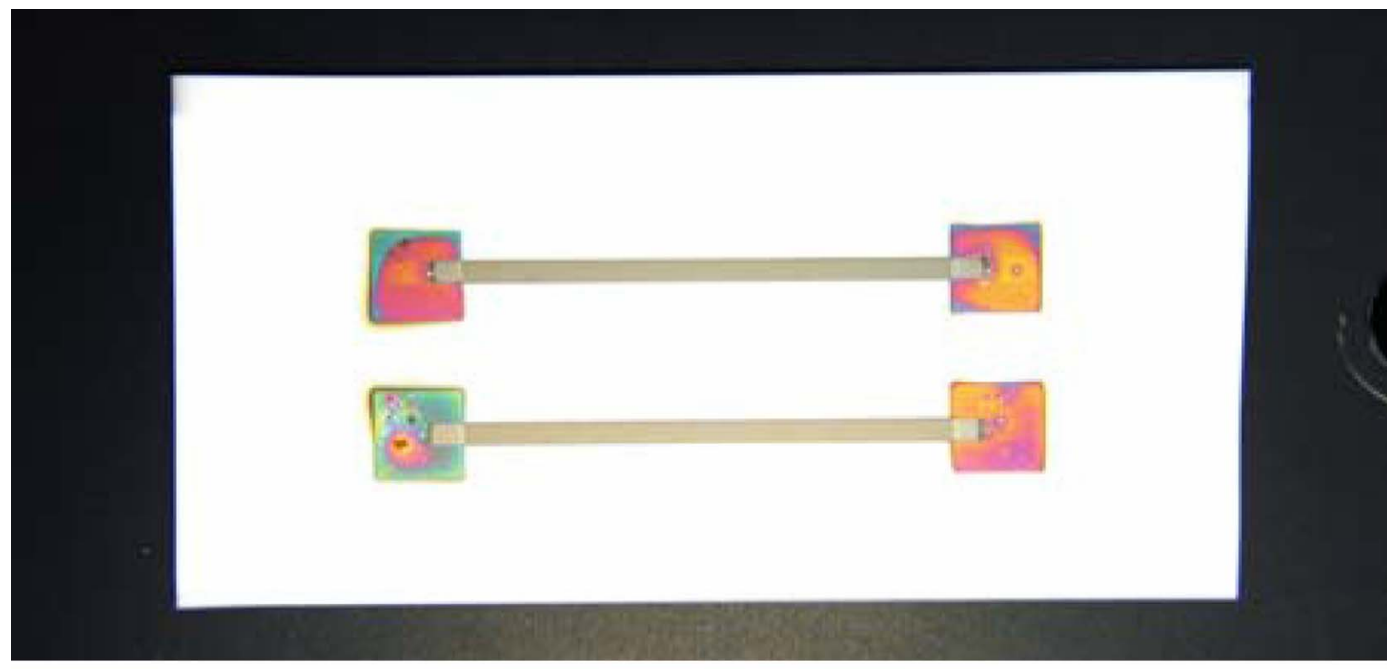

Figure 4.-TaN/PdCr multilayer samples (runs JG60427 and JG60428).

\section{B. Multilayered Film Samples}

Three sets of TaN/PdCr multilayer films were fabricated with different $\mathrm{PdCr}$ to TaN thicknesses, with each set having two samples using identical machine parameters. The films were pattered using a shadow mask with $1 / \mathrm{w}=$ 21.88 as shown in figure 4 , allowing the resistivity to be measured as well as the TCR using a four wire method with a data acquisition system. After the two samples in a set were completed, they were annealed at $600{ }^{\circ} \mathrm{C}$ in $<10^{-6} \mathrm{Torr}$ vacuum for $8 \mathrm{hr}$ to stabilize the multilayer films. The results are shown in table 3 , and the conductivity and TCR are shown in graphs in figures 5 and 6 respectively with the theoretical plot based on values of TaN from JG50115. Note that the top $560 \AA$ of the samples are being forced to be $\mathrm{TaO}$, which is used to control the passivating oxide that would normally form on TaN films. Examining each of these sets, the conductivity and TCR of JG50510 does appear to be inconsistent with the rest of the films, so much as to call into question the reaction of the formation of tantalum nitride in the fabrication process.

TABLE 3.-TaN/PdCr MULTILAYER SAMPLE PROPERTIES

\begin{tabular}{|c|c|c|c|c|c|c|c|}
\hline Sample & $\begin{array}{c}\text { TaN } \\
\text { thickness } \\
(\AA) \\
( \pm 250 \AA)\end{array}$ & $\begin{array}{c}\text { PdCr } \\
\text { thickness } \\
(\AA) \\
( \pm 250 \AA)\end{array}$ & $\begin{array}{c}\text { TaN+TaO } \\
\text { thickness } \\
(\AA) \\
( \pm 250 \AA)\end{array}$ & $\begin{array}{c}\text { Total } \\
\text { thickness } \\
(\AA) \\
( \pm 10 \text { percent })\end{array}$ & $\begin{array}{c}\text { Resistivity } \\
\left(20^{\circ} \mathrm{C}\right) \\
(\mu \Omega-\mathrm{cm}) \\
( \pm 10 \text { percent })\end{array}$ & $\begin{array}{c}\text { Conductivity } \\
\left(20^{\circ} \mathrm{C}\right) \\
(\Omega-\mathrm{cm})^{-1} \\
( \pm 10 \text { percent })\end{array}$ & $\begin{array}{c}\text { TCR } \\
\left(20 \text { to } 150{ }^{\circ} \mathrm{C}\right) \\
\left(\mathrm{ppm} /{ }^{\circ} \mathrm{C}\right) \\
\left( \pm 5 \mathrm{ppm} /{ }^{\circ} \mathrm{C}\right)\end{array}$ \\
\hline JG50331 & 5100 & 2400 & 6300 & 13800 & 186 & 5370 & -70 \\
\hline JG50401 & 5100 & 2450 & 5300 & 12850 & 171 & 5840 & -45 \\
\hline JG50509 & 5070 & 4000 & 5600 & 14670 & 152 & 6560 & -4.5 \\
\hline JG50510 & 5200 & 4000 & 5500 & 14700 & 142 & 7050 & 119 \\
\hline JG60427 & 5000 & 5860 & 6250 & 17110 & 166.1 & 6022 & 43 \\
\hline JG60428 & 5400 & 5300 & 5600 & 16300 & 173.1 & 5775 & 19 \\
\hline
\end{tabular}

As TaN films seem to vary more than annealed metallic films from bulk values in literature (refs. 9 to 12 and 26), the determination of the resistivity and TCR of the TaN films of the multilayer films will shed light on the variation of the parameters for TaN for these runs. From equations (3) and (4), the TCR and resistivity of the TaN portion of the films formed in the multilayer can be determined.

Since the thicknesses of the films individually are measured, as is the total conductivity and TCR (as shown in table 3), the TaN conductivity can be estimated from equation (3):

$$
\sigma_{\mathrm{TaN}}=\frac{\sigma_{\mathrm{Total}} d_{\mathrm{Total}}-\sigma_{\mathrm{PdCr}} d_{\mathrm{PdCr}}}{d_{\mathrm{TaN}}}
$$


Likewise, the TCR can be estimated from equation (4):

$$
\alpha_{\mathrm{TaN}}=\frac{d_{\mathrm{Total}} \sigma_{\mathrm{Total}} \alpha_{\mathrm{Total}}-d_{\mathrm{PdCr}} \sigma_{\mathrm{PdCr}} \alpha_{\mathrm{PdCr}}}{\sigma_{\mathrm{TaN}} d_{\mathrm{TaN}}}
$$

Table 4 gives the results of these calculations for the six samples. The TCR and resistivity for the TaN films for JG50510 is observed to be more similar to $\mathrm{Ta}+\mathrm{Ta}_{2} \mathrm{~N}$ mixed films than to pure $\mathrm{Ta}_{2} \mathrm{~N}$ films (ref. 9). If the $\mathrm{TaN}$ for JG50510 is included, an average resistivity and TCR for the TaN for the samples are $189 \pm 31 \mu \Omega$-cm and $-93 \pm 94 \mathrm{ppm} /{ }^{\circ} \mathrm{C}$ respectively. Without JG50510, the resistivity and TCR are $199 \pm 24 \mu \Omega$-cm and $-130 \pm 30 \mathrm{ppm} /{ }^{\circ} \mathrm{C}$. The latter values are used in the "best fit" curves in figures 5 and 6.

TABLE 4.-TaN PROPERTIES FROM TaN/PdCr DEPOSITIONS

\begin{tabular}{|c|c|c|c|}
\hline Sample & $\begin{array}{c}\text { TaN conductivity } \\
(\Omega-\mathrm{cm})^{-1}\end{array}$ & $\begin{array}{c}\text { TaN resistivity } \\
(\mu \Omega-\mathrm{cm})\end{array}$ & $\begin{array}{c}\text { TaN TCR } \\
\left(\mathrm{ppm} /{ }^{\circ} \mathrm{C}\right)\end{array}$ \\
\hline JG50331 & 4820 & 207 & -170 \\
\hline JG50401 & 5360 & 186 & -135 \\
\hline JG50509 & 5920 & 169 & -110 \\
\hline JG50510 & 6630 & 151 & 91 \\
\hline JG60427 & 4655 & 215 & -93 \\
\hline JG60428 & 4400 & 227 & -139 \\
\hline
\end{tabular}

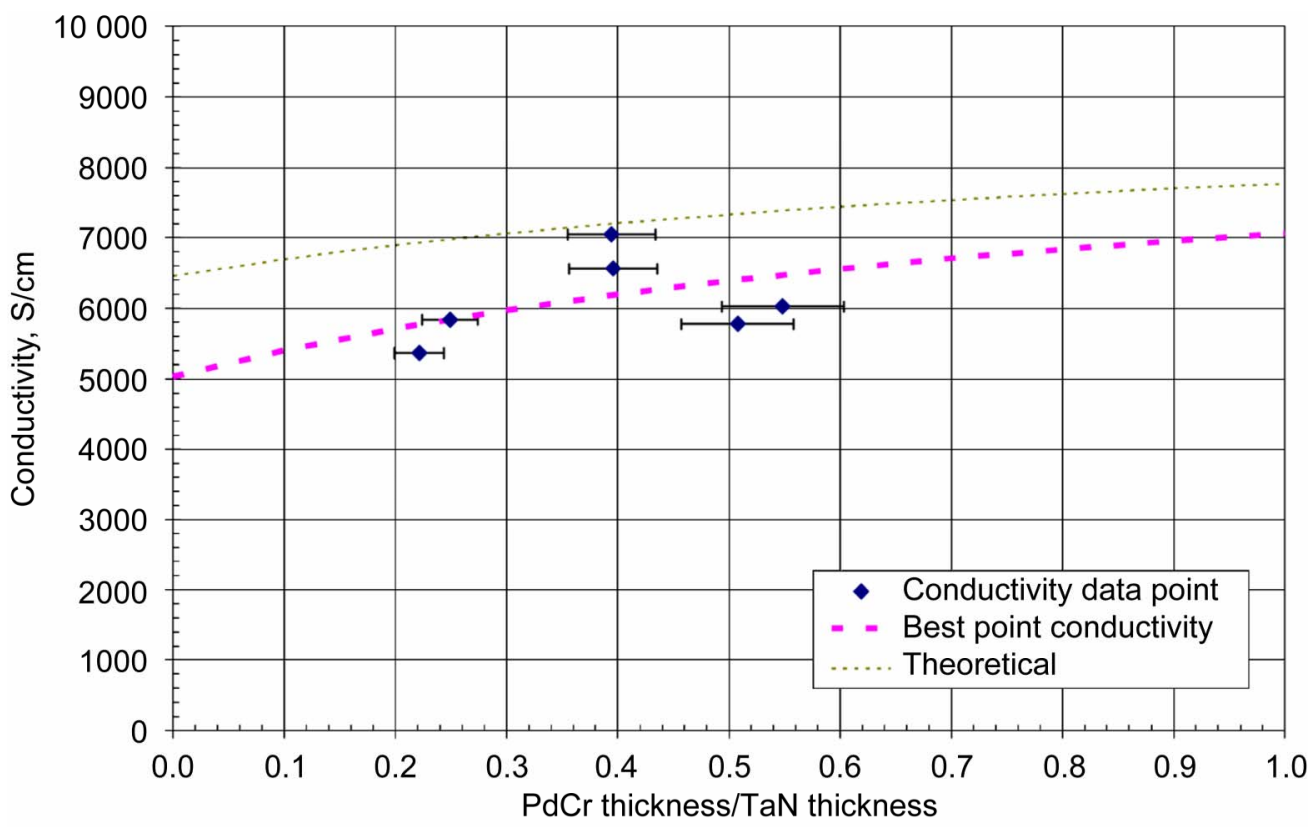

Figure 5.-Conductivity of $\mathrm{TaN} / \mathrm{PdCr}$ multilayer at room temperature versus $\mathrm{PdCr} / \mathrm{TaN}$ thickness ratio. 


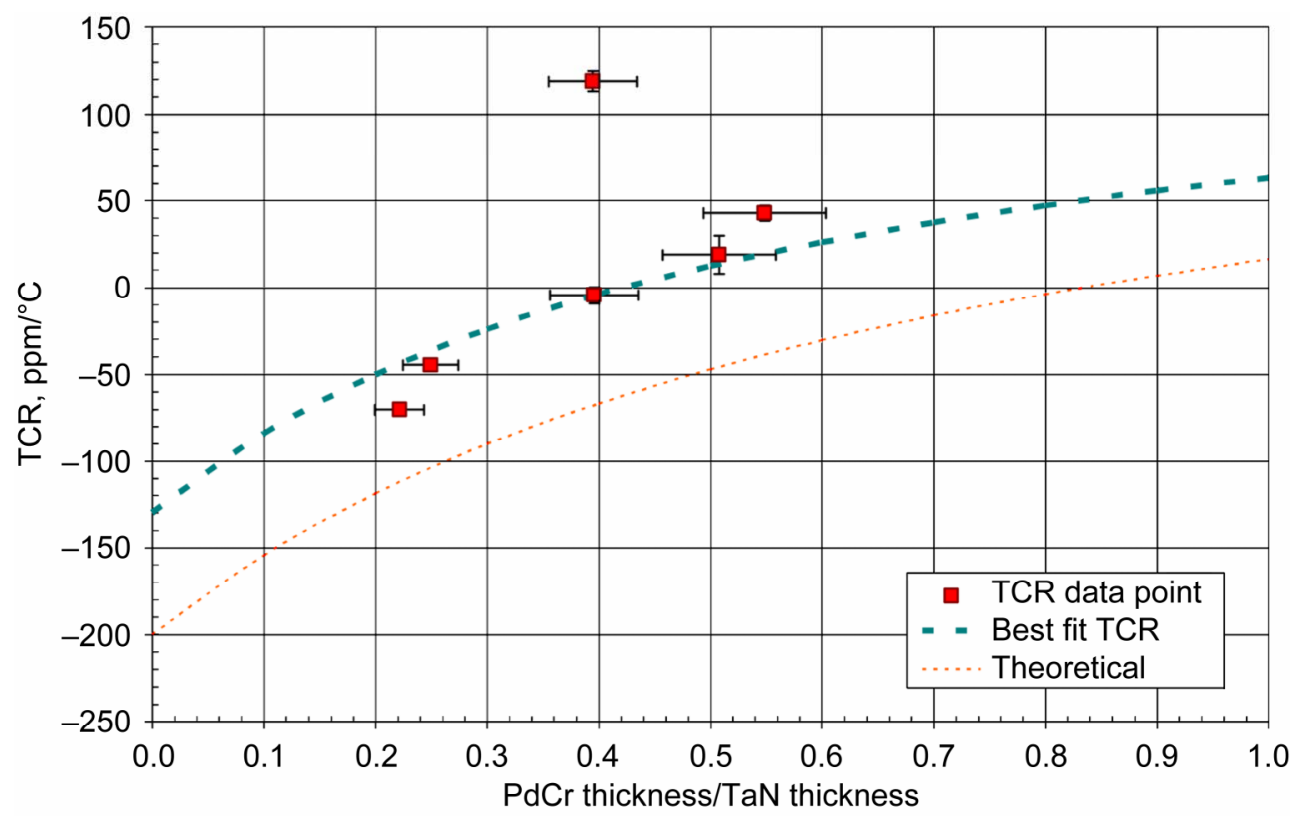

Figure 6.-TCR of TaN/PdCr multilayer versus $\mathrm{PdCr} / \mathrm{TaN}$ thickness ratio.

\section{Multilayered Thin Film Multifunctional Sensor Application}

To test the TaN/PdCr multilayer as multifunctional sensors, several multifunctional sensors were fabricated using the pattern shown in figure 7 with $1 / \mathrm{w}=447$. The properties of the sensors are summarized in table 5 , which also contains the TaN multifunctional sensor (JG40922) as a reference. The first multilayer sensor (JG51003) was fabricated using the ratio of $\mathrm{PdCr}$ to TaN of 0.32 , based on the average calculated properties of TaN in table 4 . The strain output is graphed in figure 8 . The resistivity and TCR of the first sensor were considerably different than what was expected. The second run (JG60522) has a PdCr to TaN ratio of 0.86 , which reflects the suspected incorporation of oxygen into the multilayer film through our sacrificial copper/nitric acid etch lithographic process that is used to pattern the sensors. The resistivity and gauge factor are lower, as expected with the increased PdCr, but the TCR was very erratic, varying between 0 and $30 \mathrm{ppm} /{ }^{\circ} \mathrm{C}$ over a temperature range of 20 to $120{ }^{\circ} \mathrm{C}$. The erratic TCR was due to a failure of the thermocouple leadwires that forced the use of an external thermocouple in contact with the sample in the oven. The leadwires will need to be repaired to determine a more precise TCR value. If the average $\mathrm{TCR}$ of $+15 \mathrm{ppm} /{ }^{\circ} \mathrm{C}$ is repeatable, the apparent strain sensitivity to temperature of $+12 \mu \varepsilon /{ }^{\circ} \mathrm{C}$ meets our goal of less than $\pm 20 \mu \varepsilon /{ }^{\circ} \mathrm{C}$ for static strain measurements, at least on this first level of testing. Further testing will need to be conducted to 700 and then to $1300{ }^{\circ} \mathrm{C}$ to validate the concept, similar to validation tests done on conventional high temperature flame-sprayed instrumentation.

TABLE 5.-TaN/PdCr MULTILAYER MULTIFUNCTIONAL SENSOR SAMPLE PROPERTY SUMMARY

\begin{tabular}{|c|c|c|c|c|c|c|c|}
\hline Sample & $\begin{array}{c}\text { TaN } \\
\text { thickness } \\
(\AA) \\
( \pm 250 \AA)\end{array}$ & $\begin{array}{c}\text { PdCr } \\
\text { thickness } \\
(\AA) \\
( \pm 250 \AA)\end{array}$ & $\begin{array}{c}\text { TaN+TaO } \\
\text { thickness } \\
(\AA) \\
( \pm 250 \AA)\end{array}$ & $\begin{array}{c}\text { Sample } \\
\text { resistivity } \\
(\mu \Omega \text {-cm }) \\
( \pm 5 \text { percent })\end{array}$ & $\begin{array}{c}\text { Sample } \\
\text { TCR } \\
\left(\mathrm{ppm} /{ }^{\circ} \mathrm{C}\right) \\
\left( \pm 5 \mathrm{ppm} /{ }^{\circ} \mathrm{C}\right)\end{array}$ & $\begin{array}{c}\text { Gauge } \\
\text { factor } \\
(\delta R / R / \varepsilon) \\
( \pm 5 \text { percent })\end{array}$ & $\begin{array}{c}\text { Apparent } \\
\text { strain } \\
\text { sensitivity } \\
\left(\mu \varepsilon /{ }^{\circ} \mathrm{C}\right)( \pm 10 \text { percent })\end{array}$ \\
\hline JG40922 & 39,000 & ---- & ---- & 259 & -93 & 3.9 & -24 \\
\hline JG51003 & 5095 & 3256 & 5554 & 198 & -121 & 1.89 & -64 \\
\hline JG60522 & 2900 & 4600 & 3450 & 146 & $15 \pm 15$ & 1.23 & $12 \pm 12$ \\
\hline
\end{tabular}




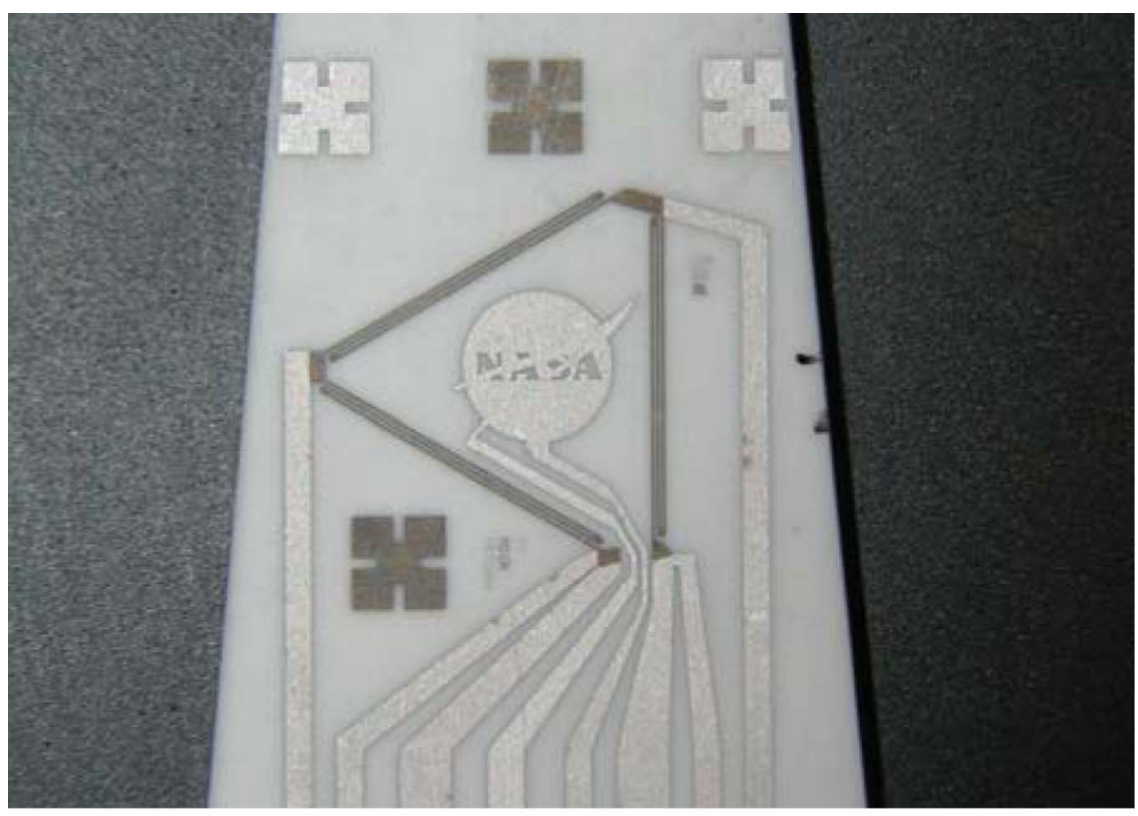

Figure 7.-TaN/PdCr multilayer multifunctional sensor rosette (run JG51003).

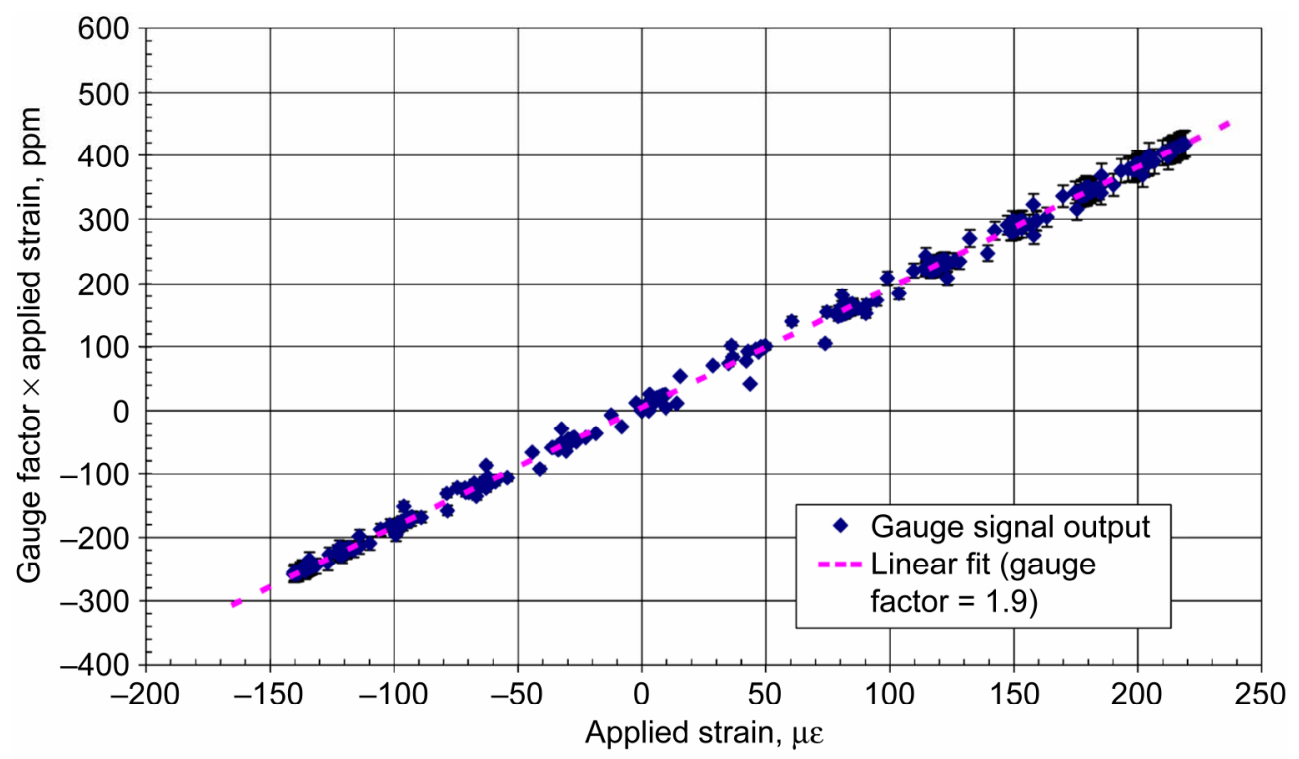

Figure 8.-Strain output of the TaN/PdCr multilayer multifunctional sensor (run JG51003). Error bars reflect $\pm 5 \%$ uncertainty in the measurement.

\section{Conclusions}

In order to have a more passive method of negating changes of resistance due to temperature, a process was developed to create a multilayer ceramic/metal thin film sensor of TaN and PdCr. The process was developed to use existing capabilities of the microfabrication cleanroom facility at NASA GRC, and to allow the fabrication of embedded sensors directly on components. The new sensor was tested on alumina substrates, since alumina is used as the typical insulator for thin film sensors on components. The sensor is capable of being fabricated in fine line widths utilizing the sacrificial-layer lift-off process that is used for microfabricated noble-metal sensors.

The TaN films were optimized for $\mathrm{Ta}_{2} \mathrm{~N}$ properties using reactive sputtering with an unbalanced magnetron source. A first approximation model of multilayer resistance and TCR was used to set the film thicknesses of PdCr and $\mathrm{TaN}$ in the multilayer film sensor. Two multifunctional sensors were fabricated using $\mathrm{TaN} / \mathrm{PdCr}$ multilayered films, and tested for low temperature resistivity, TCR and strain response. 
Though there were initial difficulties translating the large area multilayered film samples to a fine lined sensor, the sensors tested improve existing apparent strain sensitivity by at least 30 percent. The low thermal coefficient of resistance compared to existing high temperature strain gauges allows for the multifunctional sensor to be used in static measurements with little or no temperature compensation. The sensor is not attacked by acids as readily as metals, making it survivable in non-oxidizing harsh environments. The reactively-sputtered fabrication technique also allows for fairly quick fabrication times compared to other ceramic-based sensors. Further tests are required to validate the sensitivity, stability, repeatability, interference and durability of the concept.

\section{References}

1. Lei J.F. and Will H.A., "Thin-film thermocouples and strain-gauge technologies for engine applications," Sensors and Actuators A 65 (1998) 187-193.

2. Anson D. and Richerson D.W., "The Benefits and Challenges of the Use of Ceramics in Gas Turbines," Progress in Ceramic Gas Turbine Development, Volume 1-Ceramic Gas Turbine Design and Test Experience, edited by M.van Roode, M.K. Ferver, D.W. Richerson (ASME PRESS, New York, 2002) pp. 1-10.

3. Schenk B., Easley M.L., and Rickerson D.W., "Evolution of Ceramic Turbine Engine Technology at Honeywell Engines, Systems \& Services," Progress in Ceramic Gas Turbine Development, Volume 1-Ceramic Gas Turbine Design and Test Experience, edited by M.van Roode, M.K. Ferver, D.W. Richerson (ASME PRESS, New York, 2002) pp. 77-110.

4. Levine S.R., Calomino A.M., Verrilli M.J., Thomas D.J., Halbig M.C., Opila E.J., and Ellis J.R., "Ceramic Matrix Composites (CMC) Life Prediction Development-2003," NASA/TM-2003-212493 (August 2003).

5. Hulse C.O., Bailey R.S., Grant H.P., Anderson W.L., and Przybyszewski J.S., "High Temperature Static Strain Gage Development," NASA CR-189044 (NASA Lewis [Glenn] Research Center, 1991) p. A10.

6. Lei J.F., "High Temperature Static Strain Measurement with an Electrical Resistance Strain Gauge," AIAA-925039 (December 1992).

7. Wrbanek J.D., Fralick G.C., Martin L.C., and Blaha C.A., “A Thin Film Multifunction Sensor for Harsh Environments," NASA/TM-2001-211075, AIAA-2001-3315 (July 2001).

8. "Applications and Design of Thin Film Resistors," Vishay Electro-Films Technical Note 61083, December 2004, URL: http://www.vishay.com/docs/61083/appsdes.pdf [cited November 2005].

9. Gerstenberg D. and Calbick C.J., "Effects of Nitrogen, Methane, and Oxygen on Structure and Electrical Properties of Thin Tantalum Films," J. Appl. Phys. 35 (2) (1964) 402-407.

10. Hieber K., "Structural and Electrical Properties of Ta and Ta Nitrides Deposited by Chemical Vapour Deposition," Thin Solid Films 24 (1974) 157-164.

11. Sun X., Kolawa E., Chen J.S., Reid J.S., and Nicolet M.A., "Properties of reactively sputter-deposited Ta-N thin films," Thin Solid Films 236 (1993) 347-351.

12. Radhakrishnan K., Ing N.G. and Gopalakrishnan R., "Reactive sputter deposition and characterization of tantalum nitride thin films," Mat. Sci. Eng. B57 (1999) 224-227.

13. Au C.L., Anderson W.A., Schmitz D.A., Flassayer J.C. and Collins F.M., "Stability of tantalum nitride thin film resistors," J. Mater. Res. 5 (6) (1996) 1224.

14. Kayser P., Godefroy J.C., and Leca L., "High-temperature thin-film strain gauges," Sensors and Actuators A 37-38 (1993) 328-332.

15. Kazi I.H., Wilda P.M., Moor T.N., and Sayer M., "The electromechanical behavior of nichrome (80/20 wt\%) film," Thin Solid Films 433 (2003) 337-343.

16. Gregory O.J., Bruins Slot A., Amons P.S., and Chrisman E.E., "High temperature strain gauges based on reactively sputtered AlNx thin films," Surface and Coatings Technology 88 (1996) 79-89.

17. Dyer S.E., Gregory O.J., Amons P.S., and Bruins Slot A., "Preparation and piezoresistive properties of reactively sputtered indium tin oxide films," Thin Solid Films 288 (1996) 279-286.

18. Gregory O.J., You T., and Crisman E.E., "Effect of aluminum doping on the high-temperature stability and piezoresistive response of indium tin oxide strain sensors," Thin Solid Films 476 (2005) 344-351.

19. Schultes G., Schmitt M., Goettel D., and Freitag-Weber O., "Strain sensitivity of $\mathrm{TiB}_{2}, \mathrm{TiSi}_{2}, \mathrm{TaSi}_{2}$, and $\mathrm{WSi}_{2}$ thin films as possible candidates for high temperature strain gauges," Sensors and Actuators A 126 (2006) 287291.

20. Wang C.M., Hsieh J.H., and Li C., "Electrical and piezoresistive properties of TaN-Cu nanocomposite thin films," Thin Solid Films 469-470 (2004) 455-459.

21. Ayerdi I., Castaño E., Garcia-Alonso A., and Garcia F.J., "Ceramic pressure sensor based on tantalum thin film," Sensors and Actuators A 41-42 (1994) 435-438. 
22. Ayerdi I., Castaño E., Garcia-Alonso A., and Garcia F.J., "Characterization of tantalum oxynitride thin films as high temperature strain gauges," Sensors and Actuators A 46-47 (1995) 418-421.

23. Smits F.M., "Measurements of Sheet Resistivities with the Four-Point Probe," Bell System Technical Journal 37 (1958) 711-718.

24. Blaha C.A., "Photolithographic Fine Patterning of Difficult-To-Etch Metals," NASA Tech Briefs LEW-17079 (March 2002).

25. Dimmich R., "Electrical Conductance and Temperature Coefficient of Resistivity of Double-Layer Films," Thin Solid Films 158 (1988) 13-24.

26. Shivaprasad S.M. and Angadi M.A., "Temperature coefficient of resistance of thin palladium films," J. Phys. D 13 (1980) L171-2. 


\begin{tabular}{|c|c|c|}
\hline \multicolumn{2}{|c|}{ REPORT DOCUMENTATION PAGE } & $\begin{array}{l}\text { Form Approved } \\
\text { OMB No. 0704-0188 }\end{array}$ \\
\hline \multicolumn{3}{|c|}{$\begin{array}{l}\text { Public reporting burden for this collection of information is estimated to average } 1 \text { hour per response, including the time for reviewing instructions, searching existing data sources, } \\
\text { gathering and maintaining the data needed, and completing and reviewing the collection of information. Send comments regarding this burden estimate or any other aspect of this } \\
\text { collection of information, including suggestions for reducing this burden, to Washington Headquarters Services, Directorate for Information Operations and Reports, } 1215 \text { Jefferson } \\
\text { Davis Highway, Suite 1204, Arlington, VA 22202-4302, and to the Office of Management and Budget, Paperwork Reduction Project (0704-0188), Washington, DC 20503. }\end{array}$} \\
\hline 1. AGENCY USE ONLY (Leave blank) & $\begin{array}{r}\text { 2. REPORT DATE } \\
\text { August } 2006\end{array}$ & $\begin{array}{l}\text { ND DATES COVERED } \\
\text { echnical Memorandum }\end{array}$ \\
\hline \multicolumn{2}{|c|}{ Developing Multilayer Thin Film Strain Sensors With High Thermal Stability } & 5. FUNDING NUMBERS \\
\hline \multicolumn{2}{|c|}{$\begin{array}{l}\text { 6. AUTHOR(S) } \\
\text { John D. Wrbanek, Gustave C. Fralick, and José M. Gonzalez }\end{array}$} & WBS 599489.02.07.03.08 \\
\hline $\begin{array}{l}\text { 9. SPONSORING/MONITORING AGEI } \\
\text { National Aeronautics and Sp } \\
\text { Washington, DC 20546-00 }\end{array}$ & $\begin{array}{l}\text { NAME(S) AND ADDRESS(ES) } \\
\text { Administration }\end{array}$ & $\begin{array}{l}\text { 10. SPONSORING/MONITORING } \\
\text { AGENCY REPORT NUMBER } \\
\text { NASA TM-2006-214389 } \\
\text { AIAA-2006-4580 }\end{array}$ \\
\hline
\end{tabular}

\section{SUPPLEMENTARY NOTES}

Prepared for the 42nd Joint Propulsion Conference and Exhibit cosponsored by the AIAA, ASME, SAE, and ASEE, Sacramento, California, July 9-12, 2006. John D. Wrbanek and Gustave C. Fralick, Glenn Research Center; José M. Gonzalez, Gilcrest Electric and Supply Company, 3000 Aerospace Parkway, Brook Park, Ohio 44142.

Responsible person, John D. Wrbanek, organization code RIS, 216-433-2077.

\begin{tabular}{l|l}
\hline 12a. & DISTRIBUTION/AVAILABILITY STATEMENT \\
Unclassified - Unlimited & 12b. DISTRIBUTION CODE \\
Subject Category: 35 & \\
Available electronically at http://gltrs.grc.nasa.gov & \\
This publication is available from the NASA Center for AeroSpace Information, 301-621-0390. & \\
\hline
\end{tabular}

\section{ABSTRACT (Maximum 200 words)}

A multilayer thin film strain sensor for large temperature range use is under development using a reactively-sputtered process. The sensor is capable of being fabricated in fine line widths utilizing the sacrificial-layer lift-off process that is used for microfabricated noble-metal sensors. Tantalum nitride films were optimized using reactive sputtering with an unbalanced magnetron source. A first approximation model of multilayer resistance and temperature coefficient of resistance was used to set the film thicknesses in the multilayer film sensor. Two multifunctional sensors were fabricated using multilayered films of tantalum nitride and palladium chromium, and tested for low temperature resistivity, TCR and strain response. The low temperature coefficient of resistance of the films will result in improved stability in thin film sensors for low to high temperature use.

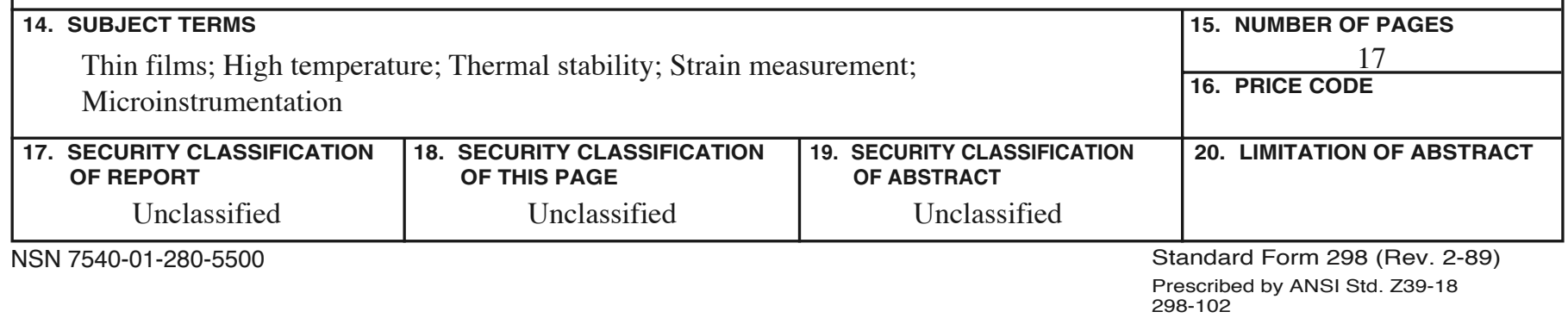



